to doubt whether the Open Court Publishing Company and Mr. Rothwell have done much service to philosophic thought by bringing forward this early thesis, or whether its republication will add much to the author's very considerable reputation in England.

(2) Miss Irvine's book is curious and interesting, and many people will read it through to the end who will be unconvinced of its value as a contribution either to science or to religion. It records under a thin veil of fiction the experiences of a young lady who could dream what she called True Dreams - that is, dreams which.were recognised as different from waking reality, but were regarded by the dreamer as incursions into some supernatural-or shall we say "astral"? plane of existence. A work of this character has no clear scientific value, but it has the merit of stimulating inquiry and directing attention to an important and little-explored field of human experience.

(3) M. Etienne Giron's essay on the problem of evil follows very closely upon the model of its prototype. His "modern Job" is a Dutch descendant of the patriarch, distinguished by the possession of great wealth and the practice of every virtue. Suffering the severest bereavements and financial misfortunes, he is comforted by three friends and by his faithful servant. The book belongs to the literature of Christian exhortation rather than to that of philosophy.

\section{ARBORICULTURAL PATHOLOGY.}

Tree Wounds and Diseases: Their Prevention and Treatment, with a special chapter on Fruit Trees. By A. D. Webster. Pp. xx $+2 \mathrm{I}_{5}$. (London: Williams and Norgate, I9I6.) Price $7 s .6 d$. net.

"TREE Wounds and Diseases" is a popular account of the nature and treatment of the ailments and injuries to which trees are liable, and may serve as an introduction to more scientific treatises like.Hartig's "Diseases of Trees" and Gillanders's "Forest Entomology." To one branch of the subject, practical tree-surgery, Mr. Webster pays more attention than these authors, who wrote from the sylviculturist's point of view. The forester handling large masses of woodland aims at the retention of only healthy and well-formed trees, from which sound timber will be ultimately harvested, and accordingly removes in his thinning operations all decaying, deformed, and injured trees. The arboriculturist is concerned with the preservation of trees for shade and ornament rather than for future use as timber, and is often called upon to repair decay and ward off impending dangers from historic and ornamental trees in parks and towns. Mr. Webster; as a practical man with considerable' experience, discusses in three short chapters such problems as the filling of hollow trunks; the support of heavy branches by iron bands and connecting rods, the guying of limbs to prevent splitting, and the pruning of diseased trees. He cites examples of old and NO. 2466, VOL. 98] decaying trees to which careful treatment has given a new lease of life, such as the elms in Regent's Park, the chestnuts in Greenwich Park, and the Wilberforce oak in Holwood Park, Kent. His remarks upon the numerous injurious influences to which trees are exposed in towns deserve attention, some of these not being generally known, as the escape of gas, which often causes the sudden and mysterious death of previously healthy trees. Piling earth round the stem, as is sometimes done in street improvements, may also prove fatal.

The chapters dealing with fungus and insect attacks are slight and sketchy, and do not contain sufficient descriptive details to render identification easy, though some of the figures may be helpful in this respect. The chapter enumerating the special enemies of each species of tree is very incomplete, and will be of little value to the forester or park superintendent, who must resort to the larger works already mentioned. This book, however, is useful as directing the attention of landowners and other non-professional readers to the many preventable causes which spoil the appearance and ultimately cause the death of much ornamental timber in Britain.

\section{OUR BOOKSHELF.}

Insect Enemies. By C. A. Ealand. Pp. xiii + 223. (London: Grant Richards, Ltd., 1916.) Price $6 s$. net.

Mr. Ealand has done good service in publishing his book on insect enemies. The work is cast in popular form, which fact may in the eyes of some detract from its merits; but, as the author justly observes, "unless and until those who have no scientific training are told of the activities of insects in language which they can understand, they can hardly be expected to be other than phlegmatic concerning the work of entomologists. The best methods of dealing with these enemies of mankind may be revealed by the comparatively few economic entomologists, but the great work of eradication can, in many cases, only be accomplished by the active co-operation of the general population." In accordance with the views here expressed, the insect pests of forest, orchard, flower and vegetable garden, farm crops, domestic animals, household, and warehouse are briefly but not inadequately dealt with, a final chapter being devoted to insects that are directly injurious to man. The treatment is naturally not exhaustive, and it may be doubted whether the remedial measures proposed are in all cases set forth in sufficient detail to be of much practical service unless the directions for use are supplemented from other sources. An appendix gives useful information as to the preparation of insecticides, though not as to the precise method of employing them. A few errors have escaped the author's notice; "Trochilium apiformis" is an awkward collocation, and in Fig. 7 the representations of male and female sawfly are reversed. 